\title{
ANALISIS EFISIENSI USAHATANI PADI DI KECAMATAN KERITANG KABUPATEN INDRAGIRI HILIR
}

\author{
Partini Partini \\ Program Studi Agribisnis Fakultas Pertanian UNISI \\ Jl. Provinsi Parit 1 Tembilahan - Riau \\ e-mail : green_tien2@yahoo.com
}

\begin{abstract}
ABSTRAK
Kabupaten Indragiri Hilir merupakan lumbung padi di Provinsi Riau, salah satu kecamatan yang merupakan produsen padi adalah Kecamatan Keritang. Penelitian ini bertujuan (1) Untuk mengetahui faktor-faktor yang mempengaruhi produksi usahatani padi di Kecamatan Keritang, (2) Untuk mengetahui tingkat efisiensi penggunaan faktor produksi padi di Kecamatan Keritang. Metode analasis data yang digunakan adalah regresi linear berganda dan fungsi produksi Cobb Douglass. Penelitian dilakukan di tiga desa yaitu Desa Seberang Pebenaan, Kelurahan Kotabaru Reteh dan Desa Kuala Keritang. Penetapan lokasi dilakukan secara purposive dengan pertimbangan bahwa daerah pada lokasi penelitian adalah produsen padi terbesar di Kecamatan Keritang. Penentuan jumlah sampel dilakukan dengan metode slovin sebanyak 98 petani, diambil secara acak. Hasil penelitian menunjukkan bahwa (1) Faktor yang berpengaruh terhadap produksi padi di Kecamatan Keritang adalah luas lahan, jumlah pestisida, jumlah tenaga kerja dan pengalaman, (2) Hasil analisis efisiensi terhadap input fisik menunjukkan bahwa luas lahan dan pestisida nilai tidak efisien NPMx/Px $>1$ (3.169 dan 3.313) sehingga penggunaannya harus ditambah sedangkan nilai $\mathrm{NPMx} /$ Px tenaga kerja $<1(-8.286)$ sehingga penggunaanya harus dikurangi.
\end{abstract}

Kata kunci : padi, efisiensi, Cobb Douglass

\section{PENDAHULUAN}

Beras merupakan komoditas pertanian yang sangat penting di Indonesia dan merupakan makanan pokok dari 98 persen penduduk Indonesia. Di samping sebagai bahan konsumsi penting dari segi pengeluaran rumah tangga, beras juga merupakan sumber kalori dan sumber protein. Selain itu beras merupakan sumber pendapatan dan kesempatan kerja bagi sebagian besar penduduk Indonesia. Dengan demikian tak heran bila beras seringkali dianggap sebagai komoditas yang bersifat strategis dan politis. Oleh karena itu keberadaan dan kecukupannya senantiasa diperhatikan oleh pemerintah (Noeriati et al, 2008).
Kabupaten Indragiri Hilir dikenal sebagai lumbung padi Provinsi Riau. Produksi padi terbesar di Indragiri Hilir berasal dari Kecamatan Keritang. Namun produksi yang besar tersebut tidak linear dengan produktivitas lahannya, dimana produktivitas padi hanya 3.935 ton/Ha. (Dinas TPHP Kabupaten Indragiri Hilir, 2014). Lokasi pertanaman padi di Kecamatan Keritang tersebar hampir diseluruh desa dimana Kelurahan Kotabaru Reteh, Desa Seberang Pebenaan, dan Desa Kuala Keritang merupakan daerah sentra dengan luas pertanaman terbesar.

Usahatani yang baik mampu memanfaatkan input yang minimum 
untuk memperoleh hasil yang optimum. Soekartawi (2001) mengemukakan bahwa optimalisasi penggunaan faktor produksi pada prinsipnya adalah bagaimana menggunakan faktor produksi tersebut seefisien mungkin. Beberapa penggunaan faktor produksi padi seperti lahan, tenaga kerja, pupuk dan pestisida perlu dioptimalkan agar tercapai produksi yang optimum. Sejauh ini, pertanaman padi di Kecamatan Keritang hanya dalam luasan dibawah 1 hektar, dilakukan sekali setahun (Indeks Pertanaman/IP 100), pemeliharaan yang tidak intensif dimana pemupukan hanya pada saat persemaian. Pengendalian gulma hanya dilakukan pada saat awal pembukaan lahan. Hal ini terjadi karena orientasi bertanam padi adalah untuk memenuhi kebutuhan sendiri dan lebih sebagai budaya.

Begitu pentingnya komoditi padi bagi masyarakat Kabupaten Indragiri Hilir khususnya Kecamatan Keritang maka penelitian ini bertujuan untuk mengkaji faktor-faktor yang berpengaruh terhadap produksi padi dan efisiensi penggunaan faktor-faktor produksi yang dialokasikan oleh petani padi dalam mencapai efisiensi ekonomis.

\section{TINJAUAN PUSTAKA}

\subsection{Faktor Produksi}

Faktor produksi adalah semua korbanan yang diberikan pada tanaman agar

tanaman tersebut dapat tumbuh dan menghasilkan dengan baik. Faktor produksi yang menentukan besar kecilnya produksi yang diperoleh adalah faktor produksi lahan, modal untuk membeli bibit, pupuk, obatobatan, tenaga kerja dan aspek manajemen. (Soekartawi, 2003). Faktor produksi pertanian meliputi:

\section{Lahan Pertanian}

Luas lahan pertanian akan mempengaruhi skala usaha dan akhirnya akan mempengaruhi efisien atau tidaknya suatu usaha pertanian. Lahan sebagai salah satu faktor produksi yang mempunyai kontribusi cukup besar terhadap usahatani. Petani yang mempunyai luas lahan yang lebih luas akan lebih mudah menerapkan inovasi dibandingkan dengan petani yang berlahan sempit. Hal ini dikarenakan keefektifan dan efisiensi dalam penggunaan sarana produksi (Soekartawi, 2003).

\section{Pestisida}

Pestisida sangat dibutuhkan petani untuk mencegah serta membasmi hama dan penyakit tanaman yang dibudidayakan. Pestisida dapat menguntungkan usahatani namun di sisi lain pestisida dapat merugikan petani. Pestisida dapat menjadi kerugian bagi petani jika terjadi kesalahan pemakaian baik dari cara maupun komposisi yang diaplikasikan ke tanaman. Pemakaian pestisida yang berlebihan dapat menyebabkan biaya produksi yang berlebihan.

\section{Pupuk}

Pupuk merupakan bahan yang dapat memberikan tambahan unsur hara pada tanaman dan tanah. Manfaat utama dari pupuk yang berkaitan dengan sifat fisik tanah adalah memperbaiki struktur tanah dan menyediakan ruang pada tanah untuk udara dan air. Selain menyediakan unsur hara, pemupukan juga membantu mencegah kehilangan unsur hara tertentu seperti $\mathrm{N}, \mathrm{P}, \mathrm{K}$ yang mudah hilang oleh penguapan. Manfaat lain dari pupuk yaitu memperbaiki keasaman tanah. Tanah 
yang asam dapat ditingkatkan pHnya dengan memberikan kapur dan pupuk organik. (Anonim, 2010)

\subsection{Fungsi Produksi Cobb Douglass}

Fungsi produksi dapat didefinisikan sebagai hubungan secara teknis transformasi input (resources) ke dalam output atau yang melukiskan antara hubungan input dengan output (Debertin, 1986). Lebih lanjut, Soekartawi (2004) menyatakan bahwa fungsi produksi dapat menggambarkan hubungan antara variabel yang dijelaskan (dependent variable) dan variabel yang menjelaskan (independent variable) serta sekaligus mengetahui hubungan antar variabel penjelas. Secara umum fungsi produksi dapat dirumuskan sebagai berikut:

$$
\mathrm{G}=\mathrm{f}(\mathrm{A}, \mathrm{K}, \mathrm{L}, \mathrm{Z})
$$

dimana $G=$ Jumlah produksi (unit), $A$ = Luas areal (unit), $\mathrm{K}=$ Jumlah modal (unit), $\mathrm{L}=$ Tenaga kerja (unit), $\mathrm{Z}=$ Faktor produksi lainnya (unit)

Fungsi produksi Cobb Douglas merupakan fungsi produksi yang umumnya dipakai para peneliti untuk penelitian terhadap produksi yang melibatkan dua atau lebih variabel faktor produksi. (Soekartawi, 2003). Secara matematika fungsi produksi Cobb - Douglas dapat ditulis sebagai berikut :

$$
\mathrm{Y}=\mathrm{aX} 1^{\mathrm{b} 1} \mathrm{X}_{2}{ }^{\mathrm{b} 2} \mathrm{X}_{3}{ }^{\mathrm{b} 3} \ldots \mathrm{X}_{\mathrm{n}}^{\mathrm{bn}} \mathrm{e}^{\mathrm{u}}
$$

Dimana $\mathrm{Y}=$ Produksi, $\mathrm{X} 1 \ldots \mathrm{Xn}=$ Faktor - faktor produksi yang digunakan, $\mathrm{a}=$ Konstanta, $\mathrm{b} 1 \ldots \mathrm{bn}=$ Parameter faktor produksi yang akan diduga, $\mathrm{u}=$ Kesalahan penduga, $\mathrm{e}=$ Logaritma natural $(\mathrm{e}=2,718)$

Persamaan tersebut akan diubah kedalam bentuk linier berganda untuk memudahkan perhitungan dengan menggunakan transformasi logaritma natural, parameternya ditentukan dengan menggunakan metode Jumlah Kuadrat Terkecil (Ordinary Least Square / OLS ) sehingga persamaan menjadi sebagai berikut (Sitepu, 2006) :

$$
\operatorname{Ln} \mathrm{Y}=\mathrm{b} 0+\mathrm{b} 1 \operatorname{Ln} \mathrm{X} 1+\mathrm{b} 2 \operatorname{Ln} \mathrm{X} 2+
$$$$
\text { b3 Ln X3 + ... bn Ln Xn }
$$

Karena penyelesaian fungsi Cobb-Douglas selalu dilogaritmakan dan diubah bentuk fungsinya menjadi fungsi linier, maka ada beberapa persyaratan yang harus dipenuhi sebelum seseorang menggunakan fungsi Cobb-Douglas. Persyaratan tersebut antara lain sebagai berikut (Soekartawi, 2003) :

a. Tidak ada nilai pengamatan yang bernilai nol. Sebab logaritma dari nol adalah suatu bilangan yang besarnya tidak diketahui (infinite).

b. Dalam fungsi produksi, (pørlu asumsi bahwa tidak ada perbedaan teknologi pada setiap pengamatan (non-neutral difference in the respective technologies). Ini artinya, kalau fungsi CobbDouglas yang dipakai sebagai model dalam suatu pengamatan; dan bila diperlukan analisis yang memerlukan lebih dari satu model katakanlah dua model, maka perbedaan model tersebut terletak pada intercept dan bukan pada kemiringan garis (slope) model tersebut.

c. Tiap variabel $\mathrm{x}$ adalah p(2) fect competition.

d. Perbedaan lokasi (pada fungsi produksi) seperti iklim adalah sudah tercakup pada faktor kesalahan.

Koefisien regresi dalam persamaan Cobb Douglas sekaligus menunjukkan elastisitas setiap variable input. Nilai returns to scale dapat dilihat dari penjumlahan semua 
koefisien elastisitas dari masingmasing input yang digunakan. Dalam persamaan diatas, besaran $\mathrm{b} 1$ dan $\mathrm{b} 2$ merupakan elastisitas $\mathrm{X}$ terhadap $\mathrm{Y}$. Secara matematis dapat ditulis (Soekartawi, 2003) :

$$
0<(\mathrm{b} 1+\mathrm{b} 2)<1
$$

Dengan

demikian, kemungkinan dari returns to scale ada tiga alternatif, yaitu (Soekartawi, 2003) :

a. Decreasing Returns to Scale, bila $(\mathrm{b} 1+\mathrm{b} 2)<1$. Dalam keadaan demikian, dapat diartikan bahwa proporsi penambahan input produksi lebih besar dari proporsi penambahan output produksi.

b. Constant Returns to Scale, (b1 $+\mathrm{b} 2)=1$. Dalam keadaan demikian, dapat diartikan bahwa proporsi penambahan masukan produksi akan proporsional dengan penambahan produksi yang diperoleh.

c. Increasing Returns to Scale, $(\mathrm{b} 1+\mathrm{b} 2)>1$. Dalam keadaan demikian, dapat diartikan bahwa proporsi penambahan input produksi lebih kecil dari proporsi penambahan output produksi.

\subsection{Efisiensi}

Menurut Soekartawi (2003), efisiensi diartikan sebagai upaya penggunaan input yang sekecilkecilnya untuk mendapatkan produksi yang sebesar - besarnya. Terdapat tiga jenis efisiensi yaitu efisiensi teknis, efisiensi harga (alokatif) dan efisiensi ekonomi. Efisiensi teknis merupakan perbandingan antara produksi sebenarnya dengan produksi maksimum. Efisiensi harga berkaitan dengan keputusan pengalokasian faktor produksi variable, biasanya menunjukkan hubungan antara nilai produk marginal suatu input dengan harga input tersebut. Efisien ekonomi adalah besaran yang menunjukkan hubungan antara keuntungan sebenarnya dengan keuntungan maksimum. Efisiensi ekonomi terjadi pada saat nilai produk marginal sama dengan harga setiap unit input tersebut, secara matematis dituliskan sebagai berikut:

$$
\begin{aligned}
& \text { NPMxi }=\text { Pxi } \\
& \text { MPPxi.Py = Pxi }
\end{aligned}
$$

Dimana:

NPMxi = Nilai Produk Marjinal dari $\mathrm{Xi}$, MPPxi = Marginal Physical Product dari Xi, Py = Harga Output Produk, Pxi = Harga Input Faktor Produksi $\mathrm{Xi}, \mathrm{Xi}=$ faktor - faktor Produksi ( $\mathrm{i}=1,2,3, \ldots \mathrm{n})$

\section{METODOLOGI PENELITIAN}

\subsection{Tempat dan Waktu Penelitian}

Penelitian dilakukan di Kecamatan Keritang Kabupaten Indragiri Hilir. pada tiga desa yang dipilih yaitu Desa Seberang Pebenaan, Kotabaru Reteh, Kuala Keritang. Penentuan lokasi penelitian dilakukan secara purposive dengan pertimbangan desa tersebut merupakan penghasil padi terbesar di kecamatan Keritang. Penelitian dilakukan pada bulan Oktober 2018.

\subsection{Jenis dan Sumber Data}

Jenis data yang digunakan meliputi data primer dan data sekunder. Data primer diperoleh melalui pengisian kuesioner meliputi data karakteristik responden, data penggunaan faktor-faktor produksi, data produksi dan data pendudkung lainnya. Data sekunder diperoleh 
melalui laporan-laporan dari instansi terkait seperti Badan Pusat Statistik (BPS), Dinas Tanaman Pangan dan Hortikultura.

\subsection{Metode Penentuan Sampel}

Penetapan jumlah sampel dilakukan dengan metode Slovin, dengan rumus sebagai berikut:

$$
\mathrm{n}=\frac{\mathrm{N}}{\mathrm{N}\left(\mathrm{d}^{2}\right)+1}
$$

dimana $\mathrm{n}=$ banyak sampel, $\mathrm{N}=$ populasi (4347 petani), $\mathrm{d}=$ nilai presisi $90 \%$ atau sig. $=0.1$. Dengan menggunakan rumus tersebut, diperoleh jumlah sampel sebanyak 98 orang. Jumlah petani yang diambil dari tiap desa diambil secara proporsional dengan jumlah masing-masing Desa Seberang Pebenaan 25 orang, Kelurahan Kotabaru Reteh 23 orang dan Desa Kuala Keritang 50 orang. Penentuan sampel dilakukan dengan secara acak sederhana.

\subsection{Metode Analisis Data}

\subsubsection{Analisis Faktor-faktor yang Mempengaruhi Produksi Padi}

Analisis faktor-faktor yang mempengaruhi produksi padi dituliskan dalam persamaan sebagai berikut:

$\mathrm{Y}=\mathrm{a}+\mathrm{b}_{1} \cdot \mathrm{X} 1+\mathrm{b}_{2} \cdot \mathrm{X}_{2}+\mathrm{b}_{3} \cdot \mathrm{X}_{3}+\mathrm{b}_{4} \cdot \mathrm{X}_{4}$

$+b_{5} . X_{5}$

Dimana $\mathrm{Y}=$ Produksi (Ton), $\mathrm{X}_{1}=$ luas lahan $(\mathrm{Ha}), \mathrm{X}_{2}=$ jumlah kumulatif pestisida (Liter), $\quad X_{3}=$ Jumlah kumulatif tenaga kerja (HOKP), $\mathrm{X}_{4}=$ Pengalaman Usahatani (tahun), $\mathrm{X}_{3}=$ Umur petani (tahun) $b_{1} . . b_{5}=$ Koefisien penduga, $\mathrm{a}=$ Konstanta.

Selanjutnya fungsi produksi input fisik dituliskan dalam persamaan Cobb Douglass sebagai berikut:

$$
\mathrm{Y}=\mathrm{aX}_{1}{ }^{\mathrm{b} 1} \mathrm{X}_{2}^{\mathrm{b} 2} \mathrm{X}_{3}^{\mathrm{b} 3} \mathrm{e}^{\mathrm{u}}
$$

Dimana $Y=$ Produksi (Ton), $X_{1}=$ luas lahan $(\mathrm{Ha}), \mathrm{X}_{2}=$ jumlah kumulatif pestisida (Liter), $\quad \mathrm{X}_{3}=$ Jumlah kumulatif tenaga kerja (HOK).

Untuk mengetahui goodness of fit dari model dapat dilihat dari koefisien determinan $\left(\mathrm{R}^{2}\right)$, untuk mengetahui pengaruh variabel bebas terhadap variabel terikat secara serentak dilakukan dengan pengujian uji $\mathrm{F}$ dan untuk mengetahui pengaruh dari masing-masing variabel bebas secara parsial digunakan uji t.

Selanjutnya untuk mengetahui pelanggaran asumsi klasik dilakukan uji autokorelasi, multikolinearitas dan heteroskedastisitas dengan ketentuan sebagai berikut:

- Uji autokorelasi dilakukan dengan melihat nilai Durbin Watson (Dw) dengan ketentuan jika $1.54<\mathrm{Dw}<$ 2.46 : tidak terjadi autokorelasi, $1.12<\mathrm{Dw}<1.54$ atau $2.46<\mathrm{Dw}$ $<2.88$ : tidak dapat disimpulkan dan $\mathrm{Dw}<1.12$ atau $\mathrm{Dw}>2.86$ : terjadi autokorelasi (Ghozali, 2005).

- Uji multikolinearitas dilakukan dengan pendekatan Varians Inflation Factors (VIF), dengan ketentuan jika nilai VIF $<10$ maka tidak terjadi multikolinearitas (Gujarati, 2000).

- Uji heteroskedatisitas dilakukan dengan metode Glejser dengan ketentuan jika nilai signifikan antara variabel independen dengan absolut residual lebih dari 0.05 maka tidak terjadi masalah heteroskedastisitas.

Sementara itu, uji kenormalan tidak dilakukan pada data per variabel tetapi pada nilai residual, dengan menggunakan uji one simple 
Kormogorov Smirnov test. Dengan ketentuan jika nilai asymp sign (2 tailed) $>0.05$ maka data menyebar secara normal.

\subsubsection{Analisis Tingkat Efisiensi Penggunaan Faktor-faktor Produksi Padi}

Efisiensi ekonomis terjadi apabila produksi mencapai efisiensi teknis sekaligus efisiensi harga. Tingkat efisiensi ekonomis dalam penggunaan input tercapai apabila dipenuhi kriteria (Soekartawi, 2003 ) :

$$
\begin{aligned}
& \text { NPMxi = Pxi } \\
& \text { MPPxi . Py = Pxi }
\end{aligned}
$$

Dimana NPMxi $=$ Nilai Produk Marjinal dari Xi, MPPxi $=$ Marginal Physical Product dari Xi, Py = Harga Output, Pxi = Harga Input Faktor Produksi Xi.

Dengan ketentuan sebagai berikut :
1) Jika NPM/Pxi $=1$, berarti penggunaan faktor produksi $\mathrm{Xi}$ sudah optimum atau sudah efisien.
2) Jika NPM/Pxi $<1$, berarti penggunaan faktor produksi $\mathrm{Xi}$ melebihi tingkat optimum atau sudah tidak efisien, sehingga penggunaannya perlu dikurangi.
3) Jika NPM/Pxi $>1$, berarti penggunaan faktor produksi $\mathrm{Xi}$ belum optimum atau belum efisien, sehingga penggu-naannya perlu ditingkatkan.

\section{HASIL DAN PEMBAHASAN}

pertanian, karena pendidikan dapat meningkatkan produktivitas petani. Semakin tinggi tingkat pendidikan petani, biasanya petani akan cepat merespon perkembangan dan teknologi yang baru. Untuk pengalaman usahatani, rata-rata 8.18 tahun. Pengalaman yang cukup lama

\subsection{Karakteristik Responden}

Salah satu faktor yang diperhatikan dalam analisis usahatani adalah karakteristikresponden karena identitas responden memberikan gambaran tentang keadaan dan latar belakang petani. Karakteristik responden dalam penelitian ini meliputi umur, lama pendidikan formal dan pengalaman usahatani disajikan pada Tabel 1 .

\begin{tabular}{|c|c|c|}
\hline No & Karakteristik & $\begin{array}{r}\text { Rata- } \\
\text { rata }\end{array}$ \\
\hline 1 & Umur (tahun) & 41.00 \\
\hline 2 & Lama pendidikan formal (tahun) & 9.96 \\
\hline 3 & Pengalaman usahatani (tahun) & 8.18 \\
\hline
\end{tabular}

Tabel 1.Karakeristik Petani Responden

Berdasarkan Tabel 1, umur responden rata-rata 41 tahun dimana umur tersebut merupakan usia produktif. semakin tua umur petani maka pertimbangan dan pengambilan keputusan relatif lebih lama dibandingkan petani yang lebih muda. Dari tingkat pendidikan formal, ratarata pendidikan formal petani 9.96 tahun atau setara tidak tamat SLTA. Pendidikan berperan dalam menentukan kemampuan petani dalam mengambil keputusan yang mempengaruhi petani dalam mengelola dan memanfaatkan sumber daya alam dan modal secara optimal. Mosher (1983), berpendapat bahwa pendidikan merupakan salah satu faktor pelancar pembangunan

ini memungkinkan petani dapat mengelola usahtaninya dengan baik dan dapat mengatasi kendala dan hambatan yang ada. Pengalaman juga mempengaruhi sikap petani dalam mengambil keputusan yang berkaitan dengan inovasi baru dibutuhkan keberanian menanggung resiko. 


\subsection{Karakteristik Usahatani pestisida dan tenaga kerja, disajikan Petani Sampel pada Tabel 2.}

Penggunaan faktor produksi dalam usahatani padi meliputi lahan,

Tabel 2. Penggunaan Faktor Produksi Padi

\begin{tabular}{llc}
\hline .No & \multicolumn{1}{c}{ Komponen } & Rata-rata \\
\hline 1 & Luas lahan usahatani padi (Ha) & 0.54 \\
2 & Penggunaan pupuk urea (Kg) & 4.69 \\
3 & Penggunaan pestisida (Liter) & 6.46 \\
4 & Tenaga kerja (HOK) & 6.70 \\
\hline
\end{tabular}

Lahan merupakan faktor Penggunaan pestisida tergolong tinggi produksi mutlak yang harus ada karena system pertanaman padi yang usahatani. Rata-rata luas lahan yang digunakan dalam usahatani padi 0.54 Ha. Penggunaan lahan yang sempit menyebabkan usahatani tidak efisien. Untuk pupuk, petani tidak melakukan pemupukan secara lengkap. Pupuk yang digunakan hanya urea, dengan jumlah rata-rata $4.69 \mathrm{~kg}$. Pupuk ini diaplikasikan pada saat persemaian. Sementara itu, untuk mendapatkan unsur hara di areal pertanaman, petani melakukan pembakaran jerami di lahan.

Pengendalian gulma dengan menggunakan pestisida rata-rata 6.46 liter. Penyemprotan dilakukan pada saat awal pembukaan lahan. dilakukan oleh masyarakat hanya sekali dalam setahun, dimana lahan dibiarkan bera menjelang musim tanam berikutnya. Hal ini menyebabkan gulma tumbuh dan lahan menjadi semak. Selanjutnya penggunaan tenaga kerja rata-rata 6.70 HOK, yang terkonsentrasi pada saat pembukaan lahan, penanaman dan pemanenan. Untuk perawatan, petani biasanya melakukan penyiangan secara manual.

\subsection{Pendugaan Model Regresi}

Hasil analisis regresi faktorfaktor yang mempengaruhi produksi padi disajikan pada Tabel 3 .

Tabel 3. Faktor-faktor yang Mempengaruhi Produksi Padi

\begin{tabular}{llcccc}
\hline No & Variabel & $\begin{array}{c}\text { Parameter } \\
\text { Dugaan }\end{array}$ & t-hitung & Signifikansi & VIF \\
\hline 1 & Konstanta & 3.759 & 3.759 & 0.000 & - \\
2 & LuasLahan & $14.340^{\mathrm{a}}$ & 14.340 & 0.000 & 8.441 \\
3 & Pestisida & $1.395^{\mathrm{e}}$ & 1.395 & 0.166 & 7.159 \\
4 & Tenaga kerja & $-5.432^{\mathrm{a}}$ & -5.432 & 0.000 & 2.144 \\
5 & Pengalaman & $1.656^{\mathrm{b}}$ & 1.656 & 0.101 & 1.499 \\
6 & Umur & $-.225^{\mathrm{ns}}$ & -.225 & 0.822 & 2.205 \\
\hline
\end{tabular}

Keterangan : (a) = taraf nyata $\alpha=1 \%(\mathrm{~b})=$ taraf nyata $\alpha=5 \%(\mathrm{c})=$ taraf nyata $\alpha=10 \%$

(d) = taraf nyata $\alpha=15 \%$ (e) = taraf nyata $\alpha=20 \%$

$\mathrm{F}$ hitung $=329.856 \quad \mathrm{DW}=2.182 \quad \mathrm{R}^{2}=0.95$

Tabel 3 menunjukkan faktor-faktor yang mempengaruhi produksi padi diperoleh nilai $\mathrm{R}^{2}$ sebesar 0.95 artinya sebesar $95 \%$ faktor produksi padi di
Kecamatan Keritang dapat diterangkan oleh variable didalam model sedangkan $5 \%$ sisanya dipengaruhi oleh faktor lain diluar model. Hasil uji 
F diperoleh nilai sebesar 329,856 (probability 0.000), hal ini berarti faktor produksi luas lahan, pestisida, tenaga kerja, pengalaman dan umur secara simultan berpengaruh terhadap produksi padi. Selanjutnya untuk uji pengaruh parsial, variabel luas lahan dan tenaga kerja berpengaruh secara nyata pada taraf $\alpha=1 \%$, variable pengalaman berpengaruh nyata pada taraf $\alpha=5 \%$ dan variable pestisida pada taraf $\alpha=20 \%$, sedangkan variable umur tidak berpengaruh nyata. Hasil uji terhadap pelanggaran asumsi klasik adalah sebagai berikut :

a. Uji autokorelasi menunjukkan bahwa nilai $\mathrm{dW}=2.182$ yang berada pada rentang nilai 1.54 $<$ Dw $<2.46$, hal ini berarti bahwa tidak tejadi autokorelasi pada variable penelitian.

b. Uji multikolinearitas menujukkan seluruh variable nilai VIF $<10$, yang dapat diartikan bahwa tidak terjadi multikolinearitas pada seluruh variable pengamatan.

c. Uji heteroskedastisitas menunjukkan seluruh nilai signifikansi $>0.05$ yang berarti tidak ada variable yang mengalami heteroskedastisitas.

Tabel 4. Hasil Uji Heteroskedatisitas

\begin{tabular}{llc}
\hline No & Variabel & Signifikansi \\
\hline 1 & LuasLahan & 0.891 \\
2 & Pestisida & 0.978 \\
3 & Naker & 0.980 \\
4 & Pengalaman & 0.649 \\
5 & Umur & 0.715 \\
\hline
\end{tabular}

Hasil pengujian normalitas terhadap residual dengan one sample Kolmogorov-Smirnov test diperoleh nilai Asymp. Sign (2 tailed) sebesar 0.981 atau lebih besar dari 0.05. Hal ini berarti bahwa residual dari regresi menyebar secara normal.

pestisida dan tenaga kerja. Hasil analisis regresi faktor produksi fisik disajikan pada Tabel 5.

Analisis efisiensi dilakukan untuk input fisik berupa luas lahan, Tabel 5. Analisis Regresi Faktor Produksi Fisik

\begin{tabular}{llcccc}
\hline No & Variabel & $\begin{array}{c}\text { Parameter } \\
\text { Dugaan }\end{array}$ & t-hitung & Signifikansi & VIF \\
\hline 1 & Konstanta & 1.968 & 9.596 & 0.000 & \\
2 & Luas Lahan & $1.126^{\mathrm{a}}$ & 15.554 & 0.000 & 7.287 \\
3 & Pestisida & $0.113^{\mathrm{d}}$ & 1.478 & 0.143 & 7.140 \\
4 & Tenaga Kerja & $-0.305^{\mathrm{a}}$ & -5.371 & 0.000 & 2.121 \\
\hline
\end{tabular}

Keterangan : a) = taraf nyata $\alpha=1 \%(\mathrm{~b})=$ taraf nyata $\alpha=5 \%(\mathrm{c})=$ taraf nyata $\alpha=10 \%$ $(d)=$ taraf nyata $\alpha=15 \% \quad F$ hitung $=543.974 \quad \mathrm{Dw}=2.198 \quad \mathrm{R}^{2}=0.95$

Tabel 5 menunjukkan input fisik yang mempengaruhi produksi padi diperoleh nilai $\mathrm{R}^{2}$ sebesar 0.95 artinya sebesar 95\% faktor produksi padi di Kecamatan Keritang dapat diterangkan oleh variable didalam model sedangkan $5 \%$ sisanya dipengaruhi oleh faktor lain diluar model. Hasil uji $\mathrm{F}$ diperoleh nilai sebesar 547.974 (signifikansi 0.000), hal ini berarti faktor produksi luas lahan, pestisida, tenaga kerja, secara simultan berpengaruh terhadap produksi padi. Selanjutnya untuk uji pengaruh 
parsial, variabel luas lahan dan tenaga kerja berpengaruh secara nyata pada taraf $\alpha=1 \%$, dan variable pestisida pada taraf $\alpha=15 \%$. Hasil uji terhadap pelanggaran asumsi klasik adalah sebagai berikut :

a. Uji autokorelasi menunjukkan bahwa nilai $\mathrm{dW}=2.198$ yang berada pada rentang nilai 1.54 $<$ Dw $<2.46$, hal ini berarti bahwa tidak tejadi autokorelasi pada variable penelitian.

b. Uji multikolinearitas menujukkan seluruh variable nilai $\mathrm{VIF}<10$, yang dapat diartikan bahwa tidak terjadi multikolinearitas pada seluruh variable pengamatan.

c. Uji heteroskedastisitas menunjukkan seluruh nilai signifikansi $>0.05$ yang berarti tidak ada variable yang mengalami heteroskedastisitas.

Tabel 6. Hasil Uji Heteroskedastisitas

\begin{tabular}{llc}
\hline No & Variabel & Signifikansi \\
\hline 1 & LuasLahan & 0.922 \\
2 & Pestisida & 0.937 \\
3 & Naker & 0.882 \\
\hline
\end{tabular}

Berdasarkan analisis regresi pada Tabel 5, dapat dituliskan model regresi linear berganda sebagai berikut:

$$
\begin{aligned}
& \text { Ln } Y=1.1968+1.126 X_{1}+ \\
& 0.113 X_{2}-0.305 X_{3}
\end{aligned}
$$

Model regresi tersebut kemudian ditransformasi dalam bentuk persamaan Cobb Douglass sebagai berikut :

$\mathrm{Y}=7.167 \mathrm{X}_{1}{ }^{1.126} \mathrm{X}_{2}{ }^{0.113} \mathrm{X}_{3}{ }^{-0.305}$

Nilai koefisien regresi pada persamaan Cobb Douglass menunjukkan besarnya elastisitas tiap faktor produksi terhadap produksi padi. Variabel luas lahan dan pestisida berpengaruh positif terhadap produksi padi. Variabel luas lahan memiliki koefisien elastisitas tertinggi sebesar 1.126 artinya apabila luas lahan bertambah $1 \%$ maka produksi padi akan meningkat sebesar $1.126 \%$ dan variabel pestisida memiliki koefisien elastisitas sebesar 0.113 artinya apabila penggunaan pestisida meningkat sebesar $1 \%$ maka produksi padi akan meningkat sebesar $0.113 \%$. Sedangkan variable tenaga kerja memiliki koefisien elastisitas negative sebesar -0.305 artinya apabila penggunaan tenaga kerja meningkat sebesar $1 \%$ produksi padi akan menurun sebesar $0.305 \%$.

Jumlah koefisien fungsi produksi padi sebesar 0.934 yang berarti bahwa proporsi penambahan input produksi lebih besar dari proporsi penambahan output produksi (Decreasing Returns to Scale). Kondisi ini disebabkan karena salah satu faktor produksi yaitu tenaga kerja bernilai negative. Secara keseluruhan penambahan faktor produksi sebesar $1 \%$ akan meningkatkan produksi sebesar $0.934 \%$.

Selanjutnya hasil analisis efisiensi ekonomis setiap faktor produksi disajikan pada Tabel 7.

Tabel 7. Analisis Efisiensi Faktor Produksi Padi

\begin{tabular}{llrrrl}
\hline No & Variabel & \multicolumn{1}{c}{ NPMXi } & $\begin{array}{c}\text { Harga input } \\
\text { (PXi) }\end{array}$ & NPMxi/Pxi & Keterangan \\
\hline 1 & Luas Lahan & $25,796,721.43$ & $8,140,000.00 \mathrm{a}$ & 3.169 & Belum optimal \\
2 & Pestisida & $215,353.55$ & $65,000.00 \mathrm{~b}$ & 3.313 & Belum optimal \\
3 & Tenaga Kerja & $-559,338.95$ & $67,500.00 \mathrm{c}$ & -8.286 & Melebihi optimal \\
\hline
\end{tabular}


Harga output $($ gabah $)=$ Rp 5.000.000/ton

$\mathrm{a}=$ sewa lahan $/ \mathrm{ha} /$ musim, $\mathrm{b}=$ harga pestisida, $\mathrm{c}=$ upah rata-rata

Tabel 7 menunjukkan nilai bahwa penggunaan faktor produksi luas lahan NPM/Px > 1 (3.169) yang berarti tidak efisien sehingga untuk meningkatkan produksi perlu penambahan luas lahan. Menurut Suratiyah (2006), dipandang dari sudut efisiensi semakin luas lahan yang diusahakan maka semakin tinggi produksi dan pendapatan per satuan luasnya. Luas lahan akan menentukan skala usahanya yang pada akhirnya akan mempengaruhi efisiensi. Namun yang menjadi kendala dalam penambahan luas lahan adalah mahalnya biaya sewa tanah. Tidak semua petani menggarap lahan milik sendiri, sehingga mereka harus menyewa kepada pemilik tanah dengan cara bagi hasil, jika dihitung setara dengan harga Rp 8,140,000/Ha. Biaya sewa lahan ini merupakan biaya terbesar dalam usahatani padi di Kecamatan Keritang sehingga petani mengabaikan faktor produksi lain seperti pupuk dan pestisida.

Faktor produksi pestisida nilai NPM/Px juga > 1 (3.313) sehingga untuk meningkatkan produksi penggunaannya harus ditambah. Penambahan pestisida perlu dilakukan untuk mengendalikan gulma dan hama penyakit di areal pertanaman. Petani hanya melakukan penyemprotan gulma diawal pembukaan lahan dan ketika terjadi serangan hama penyakit.

Sementara untuk faktor produksi tenaga kerja nilai NPM/Px < 1 (-8.286) yang berarti penggunaan tenaga kerja tidak efisien dan penggunaannya harus dikurangi. Penggunaan tenaga kerja banyak terkonsentrasi pada saat pembukaan lahan karena kondisi lahan yang dibiarkan bera sehingga menjadi belukar dan membutuhkan waktu lama untuk penyiapan lahan tanam. Kemudian proses penanaman dan pemanenan secara manual menyebabkan banyaknya curahan jam kerja.

\section{KESIMPULAN DAN SARAN}

\subsection{Kesimpulan}

1. Faktor yang berpengaruh terhadap produksi padi di Kecamatan Keritang adalah luas lahan, jumlah pestisida, jumlah tenaga kerja dan pengalaman.

2. Hasil analisis efisiensi terhadap input fisik menunjukkan bahwa luas lahan dan pestisida tidak efisien dimana nilai NPMx/Px $>1$ (3.169 dan 3.313) sehingga penggunaannya harus ditambah sedangkan nilai NPMx/Px tenaga kerja $<1 \quad(-8.286)$ sehingga penggunaanya harus dikurangi.

\subsection{Saran}

1. Tingginya harga sewa lahan menyebabkan petani mengabaikan faktor produksi yang lain, oleh karena itu perlu negosiasi ulang antara pemilik tanah dengan penyewa.

2. Petani dapat memanfaatkan tanah setelah panen padi sehingga lahan tidak semak ketika musim tanam tiba atau petani dapat meningkatkan indeks pertanaman menjadi IP 200.

\section{DAFTAR PUSTAKA}

Debertin, D.L. 1986. Agricultural Production Economics. 
McMillan Publishing Company, New York.

Dinas Tanaman Pangan, Hortikultura, dan Peternakan. Luas lahan, produksi, dan produktivitas padi Kabupaten Indragiri Hilir Tahun 2014.

Ghozali, Imam. 2005. Aplikasi Analisis Multivariate dengan SPSS. Semarang; Badan Penerbit UNDIP.

Mosher A.T. 1985. Pembangunan Pertanian. Penerbit LP3ES:Jakarta.

Noeriati, Djohar R.D., M. Harry Susanto \& Nuhfil Hanani. 2008. Simulasi Pengaruh Kebijakan Pemerintah
Terhadap Harga Beras di Indonesia. Jurnal agritek volume 16 No. 11.

Sitepu, Rasidin Karo Karo \& Bonar M. Sinaga. 2006. Aplikasi Model Ekonometrika, Estimasi Simulasi, dan Peramalan Menggunakan Program SAS. Sekolah Pascasarjana, Institut Pertanian Bogor, Bogor.

Soekartawi. 2003. Teori Ekonomi Produksi dengan Pokok bahasan Analisis Fungsi Cobb-Douglas. PT. Raja Grafindo Persada. Jakarta.

2003. Agribisnis Teori dan Aplikasinya. PT Raja Grafindo Persada. Jakarta. 